\title{
ANALYSIS OF MEDICAL AND PARAMEDIC SERVICES' EFFECT ON TREATMENT AWARENESS THROUGH SATISFACTION OF TUBERCULOSIS PATIENTS IN KENDARI, INDONESIA
}

\author{
Patwayati, Ridwan Muhammad \\ University of Halu Oleo, Kendari, Indonesia \\ *E-mail: mail@uho.ac.id
}

\begin{abstract}
The study aims to know and analyze the influence of medical personnel and paramedics' service quality on service satisfaction as well as to examine the effect of service satisfaction on the awareness of TB patients to get treatment in Kendari. The study is expected to be a source of information in the implementers of TB control programs, i.e. to provide satisfactory and effective service for patients. The results of the study suggest a positive and significant influence between the services of medical personnel to patient satisfaction; it has a path coefficient of 0.531 and $C R$ of 2.830 with a probability level of 0.005 . The influence of paramedic service to patient satisfaction shows a path coefficient of 0.002 and CR of 0.02 with a probability level of 0.984 ; this shows a positive but not significant influence. The effect of patient satisfaction on the awareness of treatment shows a path coefficient of 1.261 and CR. 2.09 with a probability level of 0.009 ; this shows that patient satisfaction has a positive and significant effect on the awareness of treatment.
\end{abstract}

\section{KEY WORDS}

Quality, satisfaction, service, health, patients.

Health development is an effort to fulfill one of the basic rights of the people, namely the right to obtain health services in accordance with the 1945 Constitution Article $28 \mathrm{H}$ paragraph (1) and Law Number 23 of 1992 on Health. Health development should be viewed as an investment to improve the quality of human resources, which among others is measured by the Human Development Index (HDI). In HDI, health is one of the main components besides education and income. Throughout the years, Indonesia has made significant progress in improving the health of the population. Indonesia's Demographic and Health Survey (IDHS) data showed infant mortality decreased from 46 (IDHS, 1997) to 35 per 1,000 live births (IDHS, 2002-2003) and maternal mortality decreased from 334 (IDHS, 1997 ) to 307 per 100,000 live births (IDHS 2002-2003). Life expectancy increased from 65.8 years (Susenas, 1999) to 66.2 years (Susenas, 2003). However, in an effort to improve quality health services, new problems and challenges arise as a result of socio-economic changes as well as changes in the global and national strategic environment. Global challenges include the achievement of Millennium Development Goals (MDGs) and the implementation of decentralization in the health sector in the national scope. The implementation of health decentralization is based on the health for all paradigm, which means that health services as a public service must be accessible to all levels of society. Health decentralization makes the health sector a local government's affair that must be accountable to the public. One of the problems faced in the health sector is the double burden of disease. The illness suffered by the community are mostly contagious or infectious diseases such as pulmonary tuberculosis, acute respiratory infections (ARI), malaria, diarrhea, and skin diseases, and at the same time an increase of non-communicable diseases such as heart and blood vessel disease as well as diabetes mellitus and cancer.

Pulmonary tuberculosis (TB) is still a public health problem in Indonesia, where the results of Household Health Survey (HS) indicate that pulmonary TB is the third leading cause of death after cardiovascular disease and respiratory disease in all age groups and is the first leading cause of death in the class of infectious diseases. The pulmonary TB control program using Directly Observed Treatment, Short Course Chemo Therapy (DOTS) strategy 
has been implemented in Southeast Sulawesi Province and Kendari since 1995, but the conversion rate in 2006 in Kendari only reaches $70 \%$ and $79.4 \%$ so that many new pulmonary tuberculosis and positive Acid Fast Basil (AFB) patients who experienced BTA conversion failure remained positive at the end of intensive phase treatment.

Failed conversion happens due to laboratory errors, as an exapmle is the $3 \%$ laboratory errors in 2006. In addition, the medical and paramedic factors contribute to the failure of the conversion at the end of the intensive phase. Of the 30 medical personnel who handle AFB positive, 9 people or $17 \%$ have not been trained. Meanwhile, from 15 paramedics who handled AFB positive, no one has ever attended the training.

On the other hand in the treatment of AFB positive, condition and perception of the patient is very decisive. Although trained medical and paramedical personnel are supported by adequate infrastructure, low patient's active role will simply leave positive AFB conversion high.

The role of doctors (medical personnel) is most dominant in the health care unit, especially in diagnosis and therapy. The Health Law Number 23 of 1992 explains that medical personnel is obliged to comply with professional standards and respect the patient in performing their duty.

Paramedics (nurses) is a noble profession in the field of health. Nursing services according to WHO Expert Committee on Nursing (Aditama, 2006) are combination of health sciences and art of caring, a humanistic combination of science and nursing philosophy. Paramedics should be able to make efforts to promote and maintain health and prevent disease.

The availability and quality of facilities and infrastructure of the health care unit is crucial to the successful rehabilitation and healing of the disease. Insufficient infrastructure doubled with inadequate quality will caues the failure of disease healing. As a result, patients are not satisfied with the services provided by the health care unit.

The concept of satisfying the needs of consumers is the main pillar of today's business, both manufacturing companies and service companies. The industry and services are very diverse. One of the service industry offered is hospital either by the government or private.

Kotler and Armstrong (2001) say that the marketing program consists of intangibility, inseparability, service variability, and perishability. In relation to the health service unit, the products are the form of preventive, diagnostic, and therapeutic services. These should consider the patients' complaints, i.e. what services must be given to eliminate and cure illness, extend life span, and reduce disability.

The function, quality, and benefits of a product are the focus of consumer attention. Consumer needs are increasing and based on a higher level of criticality; they tend to demand personal services involved in the development of a product (Hadiati and Ruci, 1999). This is the basis for thinking to keep meeting the needs and expectations of customers in all changes so they will not turn to substitution products.

The service quality concept of Bromeer, Ruyter, and Peters (in Zaid, 2004) suggests that the quality of services offered by a company will affect the level of customer loyalty that leads to the level of satisfaction. Many studies adapted findings obtained by Parasuraman et al. and they always connect the service quality to customer satisfaction. Oliver (in Djati and Dharmawan, 2005) defines satisfaction as an attitude toward the outcome of the transaction.

The level of satisfaction according to Cronin and Taylor (1992) is a gap between what consumers expect before buying product or service with the feeling after they evaluate the purchase. A level of expectation smaller or equal to what one feels for the performance of the product purchased will create a level of satisfaction, and the vice versa, if customer expectations are greater than the actual product performance, then dissatisfaction follows. follows:

Based on the above explanation, the subject matter and purpose of this study is as

1. Does the service quality of medical personnel have a positive and significant effect on satisfaction?

2. Does the service quality of paramedics have a positive and significant effect on satisfaction? 
3. Does satisfaction have a positive and significant effect on treatment awareness?

The study aims to:

1. Examine and analyze the effect of service quality of medical personnel to satisfaction of TB patients

2. Examine and analyze the effect of service quality of paramedics to satisfaction of TB patients

3. Examine and analyze the effect of satisfaction to treatment awareness of TB patients

\section{LITERATURE REVIEW}

According to Zeithaml in Zaid (2004), service quality is defined as the degree of difference between consumer expectations and consumer perceptions. Consumer expectations of a service offered are influenced by would of mouth communication, i.e. anything heard or received by the customer through another person consisting of:

1. Personal needs, i.e. the level of a person needs toward a certain product or service company.

2. Past experience, i.e. experienced customer has in using a product or service of a particular company.

3. External communication, i.e. the information submitted by the company to the public.

Experts in the field of service management have conducted many studies to know in detail the dimensions of services that affect the quality, including determining which dimension is the most decisive in the quality of certain services. According to Van Looy et al. (in Jasfar, 2005), an ideal dimension of service quality model must meet several conditions, such as the following:

1. The dimension must be a comprehensive unit, meaning it can explain the overall characteristics of the perception of quality because of the differences of each proposed dimension.

2. The model must also be universal, meaning that each dimension must be general and valid to share the spectrum of services.

3. Each dimension in the proposed model should be free.

4. The number of dimensions is limited.

According to Gonroos, the quality of service from the point of customer valuation is distinguished on the following three dimensions.

1. Technical or outcome dimension, which is related to what is given by consumers. This dimension is synonymous with what is called as competence by Parasuraman.

2. Functional or process related dimension, which is related to the way services are delivered or presented.

3. Corporate Image, which is related to corporate image in the eyes of consumers. This dimension is the same as credibility by Parasuraman.

Johnston et al. undertook research in the United Kingdom (Britain) and proposed eighteen dimensions of service quality with their respective definitions, as shown in the notes put forward by Van Looy et al. as follows:

1. Access, i.e. an easily accessible location, including the ease of finding the surrounding streets and the clarity of the route.

2. Aesthetics, i.e. the extent to which service packs are available to satisfy consumers.

3. Attentiveness or helpfulness, i.e. personnel contact, the extent to which they wish to help the consumers.

4. Availability, i.e. the availability of service facilities, staff, and goods for consumers.

5. Care, i.e. caring, attention, sympathy, and patience shown to consumers.

6. Cleanliness or tidiness, i.e. cleanliness, neatness, and regularity of physical products in the service package.

7. Comfort, i.e. the comfort of the environment and service facilities.

8. Commitment, i.e. workers' commitment to the task.

9. Communication, i.e. the ability of service providers to communicate with consumers.

10. Competence, i.e. expertise and professionalization in service delivery 
11. Courtesy, i.e. respect in the provision of services, especially with regard to staff contact in connection with the consumers and their property.

12. Flexibility, i.e. the willingness of workers to change the service or product, in accordance with the expectation of consumers.

13. Friendliness, i.e. the warmth and familiarity of service providers, especially staff contacts.

14. Functionality, i.e. the ability of the service or the suitability of product quality, either in the form of service facilities or goods.

15. Integrity, i.e. honesty, fairness, trust given by service companies to consumers.

16. Security, i.e. the safety and security of consumers and their role in the service process

17. Reliability, i.e. reliability and consistency of performance of service facilities, goods, and staff.

18. Responsiveness, i.e. speed and accuracy of service delivery.

Parasuraman, Zeithaml, and Berry perform special research on several types of service industries. Prior to grouping into five dimensions, the three researchers identify the ten factors assessed by consumers and the factors that determine the quality of services, i.e. access, communication, competence, courtesy, credibility, responsiveness, security, understanding, and tangible.

Furthermore, Parasuraman et al. conduct a focus group discussion, both users and service providers. The results show a very strong relationship between communication, competence, courtesy, credibility, and security which are then grouped into one dimension, namely assurance. Similarly, they find a very strong relationship between access and understanding, which is then combined into one dimension, empathy. Finally, Parasuraman proposes five dimensions of service quality. These five dimensions are reliability, responsiveness, assurance, empathy, and tangible (physical products).

Based on what is stated by Parasuraman, the measurement of service quality in this study is Tangibles $\left(X_{1}\right)$, Reliability $\left(X_{2}\right)$, Responsiveness $\left(X_{3}\right)$, Assurance $\left(X_{4}\right)$ and Emphaty $\left(X_{5}\right)$.

Oliver in Umar (2003) states that customer satisfaction is defined as an after-purchase evaluation, where perceptions of alternative performance of products or services selected meet or exceed expectations before purchase. If perceptions of performance cannot meet expectations, then dissatisfaction happens. Kotler (2000) defines satisfaction as the level of one's feelings after comparing the performance of the product (or outcome) that he feels with his expectations. Thus, the level of satisfaction is a difference between perceived performance and expectations. According to Spreng, Mackenzie, and Olshvskhy (1996), customer satisfaction is the feeling perceived by customers from the performance of companies that meet their expectations. However, from the perspective of consumer behavior, customer satisfaction then becomes something complex. Behavior after purchase or use will lead to a dissatisfied or unsatisfied attitude, so consumer satisfaction is buyer's expectations toward the product or service compared with perceived performance.

J. Paul Peter and Jerry C. Olson (2000) confirm that consumer satisfaction is an important concept in consumer marketing and research. It is a common opinion that if consumers are satisfied with a product or brand, they are likely to continue to buy and use it and tell others about their pleasant experience with the product. If they are not satisfied, they tend to switch brands and appeal to producers, retailers, and even tell others. Band in Musanto (2004) affirms that customer satisfaction is a level where the needs and expectations of the customer can be fulfilled which will result in repeat purchase or continued loyalty. According to Tjiptono (1997), customer satisfaction or dissatisfaction is a customer response to products or services, which match or mismatch previous expectations.

Umar (2003) uses the 6 commonly used concepts to measure satisfaction, as follows:

1. Overall customer satisfaction, i.e. by asking customers about their level of satisfaction of the services concerned and asking them to assess and compare with the overall level of satisfaction for the services they receive from competitors. 
2. Dimensions of customer satisfaction, which is done through four steps. First is identification on the key dimensions of customer satisfaction. Second is to ask the customer to assess the services of the company based on specific items such as the speed of service or the friendliness of the customer service staff. Third, we ask customers to assess competitor services based on the same specific items. Fourth, customers have to determine the dimensions they think important in assessing overall customer satisfaction.

3. Confirm expectations, i.e. satisfaction is not measured directly, but is concluded based on the suitability or disagreement between customer expectations and the actual performance of services the company sells.

4. Interest in re-purchase, i.e. customer satisfaction is measured by whether they will repurchase the same services or not.

5. Willingness to recommend, in which it is an important measure, especially for services that are relatively taking long time, such as higher education services.

6. Customer dissatisfaction, which can be reviewed, for example in the case of complaints, warranty fees, negative word of mouth, and defections.

Kotler (2001) suggests measuring customer satisfaction using the following methods:

1. Customer satisfaction surveys, i.e. companies respond directly to measure customer satisfaction by conducting regular surveys. They send questionnaires or call the latest customer samples to find out how they feel about various aspects of company performance.

2. Complaint and suggestion delivery system, i.e. customer-centered organizations make it easy for customers to submit suggestions or complaints. Such a system not only helps the company to act quickly to solve its problems, but also gives the company many good ideas to improve its products and services.

3. Attentive front line personnel, i.e. employees who have direct contact with customers can be excellent sources of information about customer satisfaction. They are the first to know what pleases the customer and what is disappointing. Front-line employees can find the problem quickly, which prevents continuing disappointment.

4. Analysis of customer defection, i.e. companies must contact customers who have stopped buying, or those who have switched to a competitor, to learn why this is happening.

Tsiros and Mittal in Zaid (2004) used two measures of consumer satisfaction, namely (1) pleased with product performance and (2) satisfaction with product performance. Then, Jamal and Nasser in Zaid (2004) gave three items of measurement, namely (1) completely satisfied by product performance, (2) conformity of product performance with expectations based on information, and (3) amazing product performance. In addition, Zaid (2000) also provides different measurements on customer satisfaction, namely (1) suitability; and (2) conformity with expectations.

Based on the information, this study uses the approach of satisfaction indicator from Kotler (2000) and Tjiptono (1997), i.e. speed of service, hospitality, and service assessment.

According to Kozier (2010), compliance or awareness of treatment is the behavior of individuals (such as taking medicine, obeying diet, or making lifestyle changes) as recommended. The level of compliance can be seen from taking into account every aspect of recommendation to comply with the plan. Sarafino (in Yetti et al., 2011; in Tritiadi, 2007) defines compliance or awareness as how patients follow the suggestions given by the doctor. Sacket (in Neil Niven, 2000) defines patient compliance as the extent of patient behavior in accordance with provisions provided by healthcare professionals. Patients may not adhere to goals or may simply forget or misunderstand the instructions given. Then, Taylor (1991) defines treatment awareness as a behavior that indicates the extent to which individuals follow health or disease-related advice. Delameter (2006) defines adherence as an active, conscious, and collaborative involvement of patients on behavior that supports their own health. La Djabo (2004) states that treatment awareness is very influential on the recovery of pulmonary tuberculosis patients. According to Kozier (2010), factors affecting compliance are (1) the patients' motivation to heal, (2) the level of lifestyle changes needed, (3) the 
perception on the severity of health problems, (4) the value of reducing the threat of disease, (5) the difficulty of understanding and performing specific behaviors, (6) the extent of the disease or the course of therapy, (7) the thought whether the programmed therapy will be helpful or unhelpful, (8) the complexity of the therapy, (9) the proposed side effects, (10) certain cultural heritages that make compliance difficult, and (11) the level of satisfaction and quality and type of relationship with health services. Based on the theory presented, the indicator in this study according to La Jabo (2004) and Kozier (2010) is regular treatment, invite others to seek for treatment, and inform the treatment.

From the literature review, the hypotheses proposed in this study are as follows:

Hypothesis 1: There is a positive and significant relationship between quality of service of medical personnel and the satisfaction of TB patients.

Hypothesis 2: There is a positive and significant relationship between quality of service of paramedic and the satisfaction of TB patient.

Hypothesis 3: There is a positive and significant influence between satisfactions of TB patients to treatment awareness.

The hypothetical relationship between the quality of service and the treatment awareness through satisfaction can be seen in the following figure:

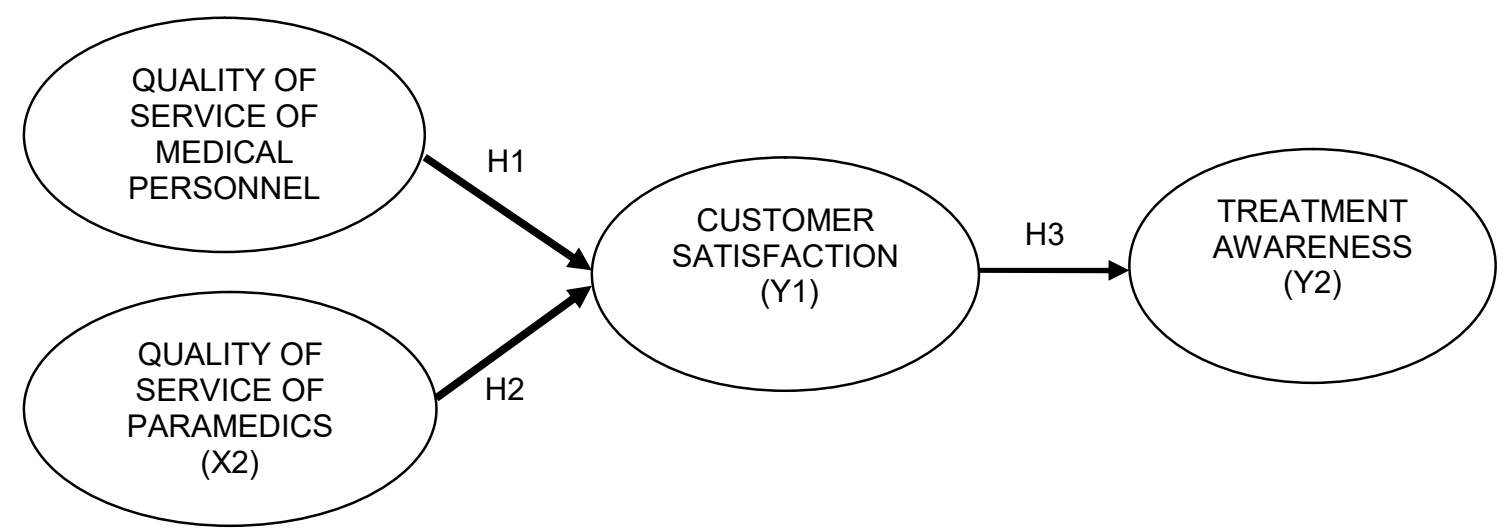

Figure 1 - Hypothetical relationship between service quality, satisfaction, and treatment awareness

\section{METHODS OF RESEARCH}

Study Site and Time. This study was conducted at the community health service unit in Kendari serving TB patients. Data in this study included respondents' opinion on the quality of medical personnel, paramedics, and patient satisfaction. This study was done for 2 months. Data was collected using questionnaires followed by interviews with respondents including patients, medical personnel, paramedics and laborants. Likert scale with score interval 1 to 5 was used. The research instrument was first tested to know the validity and reliability. The validity test showed valid because the correlation coefficient shown was smaller than the significance 0.05 , while the reliability test showed a result smaller than 0.60 then each variable was declared reliable. Furthermore, results of questionnaire and interviews were analyzed using SPSS and AMOS.

Population and Sample. Population in this study was all patient of AFB TB Positive in Kendari undergoing treatment at the Health Service Unit serving TB patients. Sampling was done by proportional random sampling, by determining the number of samples to be taken at each TB Treatment Center proportionally. Determination of the sample at each TB treatment center was done randomly, based on the list of patients available to the Health Service Unit serving the TB patient. Determination of the number of samples from the population was done by following the criteria of the analytical equipment used, i.e. SEM. The sample size used, according to Hair et al. in Ferdinand (2005), is 100-200, and the minimum sample size was five observations for each parameter estimated. Thus, the minimum sample size in this 
study was $5 \times 8=40$, but to meet the appropriate sample size criteria, the sample size determined in this study was 120 respondents.

Data Analysis Method. The analysis used to answer the hypotheses in this study was Structural Equation Model (SEM) using AMOS 5.0 program package. Before the hypothesis testing, first a factor confirmatory analysis to see the dimensions used to form factors or constructs was done.

\section{RESULTS OF STUDY}

The Effect of Service Quality of Medical Personnel toward Patient Satisfaction:

Table 1 - Path Coefficient (Standardized Regression) Relationship between Variables

\begin{tabular}{|c|c|c|c|c|}
\hline PATH & PATH COEFF & CRITICAL RATIO & PROB & NOTE \\
\hline $\mathrm{KPTM} \rightarrow \mathrm{KP}$ & 0,531 & 2,803 & 0,005 & Significant \\
\hline $\mathrm{KPPM} \rightarrow \mathrm{KP}$ & 0,002 & 0,020 & 0,984 & Not Significant \\
\hline $\mathrm{KP} \rightarrow \mathrm{KB}$ & 1,261 & 2,609 & 0,009 & Significant \\
\hline
\end{tabular}

Note: KPTM - Service quality of medical personnel; PPPM - Service quality of paramedics; KP - Patient satisfaction; $K B$ - Treatment awareness.

Table 1 shows the path coefficient for the effect of service quality by medical personnel service to satisfaction, which is 0.531 and CR 2.830 with a probability level of 0.005 . This shows that the first hypothesis is accepted. The ability of medical personnel in carrying out their responsibilities is greatly contributes to a good assessment of the quality of care by TB patients. Low capability of the medical personnel may affect the healing process of the patients.

The Effect of Service Quality of Paramedics toward Patient Satisfaction. Table 1 shows a path coefficient (standardized regression) for the effect of service quality of paramedics toward patient satisfaction, which is 0.002 and CR 0.02 with a probability level of 0.984 . The results indicate that the second hypothesis is rejected-the paramedic services has a positive but not significant effect to satisfaction; many factors affect this, among them is the fact that the responsibility of healing the patient is generally still the responsibility of medical personnel. Any actions to be performed to patients should be consulted to the medical personnel. As such, paramedics may feel that their responsibility is not as big as the medical personnel, and they leave things more to the medical personnel. For example, patients in a critical situation are generally more relieved if medical personnel help them.

Another thing that causes the insignificance of paramedic services is the limited available personnel and training. Of the 36 existing health facilities in Kendari, only one paramedic assigned to TB service while the number of patients is high, not to exclude mutation of paramedics to other regions.

The Effect of Satisfaction toward Treatment Awareness. Table 1 shows the path coefficient on the effect of satisfaction to treatment awareness, which is 1.261 and 2.609 with a probability level of 0.009 . This shows that the third hypothesis is accepted. This shows that satisfaction has a positive and significant effect toward treatment awareness, marked by the willingness of patients to take the medicine. The better the service received by the patients, the higher their satisfaction, which leads to better treatment awareness-and the vice versa. The patients' psychological commitment to health care, their rationality, and the word of mouth they make can shape the cooperative behavior toward treatment.

\section{CONCLUSION AND RECOMMENDATIONS}

Based on the analysis and findings, some conclusions can now be drawn on the quality service off the medical personnel and paramedics, satisfaction, and treatment awareness of TB patients in Kendari, as follows:

There is a positive and significant influence between the quality services of medical personnel to patient satisfaction, which means that the first hypothesis is accepted. This 
indicates that the ability of medical personnel in handling TB cases in Kendari is satisfying for the patients.

There is a positive but not significant influence between the quality services of to patient satisfaction, which means that the second hypothesis is rejected. One of the reasons is the fact that the responsibility of healing the patient is generally still the responsibility of medical personnel. Any actions to be performed to patients should be consulted to the medical personnel. As such, paramedics may feel that their responsibility is not as big as the medical personnel, and they leave things more to the medical personnel. The other thing that causes the insignificance of paramedic services is the limited available personnel and training.

Satisfaction has a positive and significant effect toward treatment awareness, marked by the willingness of patients to take the medicine. The better the service received by the patients, the higher their satisfaction, which leads to better treatment awareness-and the vice versa.

In general, the service quality of medical personnel and paramedic services affects positively the awareness of TB patients to get treatment. This shows the service quality can be accounted for. The number of patients was 338 people with a cure rate of 330 people or $97.3 \%$. Therefore, the ability of medical personnel and paramedics in giving service is satisfying for the patients leading to better treatment awareness.

Recommendations:

Further studies on the same topic are suggested to test on health personnel taking care of TB patients in more advanced places.

This study confirms that there is a positive but not significant effect of paramedic abilities to patient satisfaction and treatment awareness; thus, we recommended further research to see if there is a direct effect of service quality to satisfaction and treatment awareness of TB patients.

Further research is expected to elaborate more literature review so the research indicators can be more complex.

Further research must develop a model by adding some moderating or intervening variables so the results can be more complex such as sociological characteristics of the community as well as the type, quantity and quality of health information.

\section{REFERENCES}

1. Aditama, Tjandra Yoga, 2006, Manajemen Aministrasi Rumah Sakit, edisi kedua, UIPress, Jakarta

2. Carauana, Albert. 2002, SERVICE LOYALTY. The Effect of Service Quality and The Mediating Role of Customer Satisfaction, European Journal of Marketing. Vol. 36. No. 7/8. pp 811-828

3. Djati, Pantja S, \& Dharmawan Didit. 2005, Pengaruh Kinerja Karyawan terhadap Kepuasan, Kepercayaan dan Kesetiaan Pelanggan, Jurnal Manajemen Kewirausahaan, Maret, vol 7 no 1, p $48-59$

4. Dharmayanti, Diah, 2006. Analisis Dampak Service Performance dan Kepuasan Sebagai Moderating Variable terhadapLoaylitas Nasabah (Studi padfa Nasabah Tabungan Bank Mandiri Cabang Surabaya, Jurnal Manajemen Pemasaran, April, V0I 1 no 1, p $35-43$

5. Furlerton \& Taylor. 2002, Mediating Interctive, and Non-Linear Effects In Service Quality and Satisfaction With Service Research, Jurnal of Marketing, Juli, vol 56, p 56 - 68

6. Ferdinand, Augusty. 2005, Structural Equation Modeling dalam Penelitian Manajemen, BP UNDIP, Semarang

7. Hasan, Iqbal M. 2002, Pokok-Pokok Materi Metodologi Penelitian dan Aplikasinya, Ghalia Indonesia, Jakarta

8. Hakim, Andi, 2006. Pengaruh Kualitas Pelayanan Terhadap Kepuasan Pelanggan Dalam Mengirim Barang (Paket Pos) pada PT. Pos Indonesia (Persero) Kendari. Tesis Program Studi IImu Manajemen Program Pascasarjana Universitas Haluoleo, Kendari (tidak dipublikasikan) 
9. Hadiati \& Ruci. 1999, Analisis Kinerja Kualitas Pelayanan Terhadap Kepuasan Pelanggan Pada Telkomsel Malang Area, Jurnal Manajemen dan Kewirausahaan, September, Vol 1, No. 1, p, 56 -64

10. Jasfar, Farida, 2005. Manajemen Jasa cetakan pertama, Ghalia Indonesia, Ciawi-Bogor

11. J. Supranto, 1997. Pengukuran Tingkat Kepuasan Pelanggan :untuk Meramaikan Pangsa Pasar, Rineka Cipta, Jakarta.

12. Kotler \& Amstrong, 2001. Prinsip-Prinsip Pemasaran (terjemahan) edisi kedelapan jilid 1, Erlangga, Jakarta

13. Kotler \& Amstrong, 2001. Prinsip-Prinsip Pemasaran (terjemahan) edisi kedelapan jilid 2, Erlangga, Jakarta

14. Kotler dkk, 2000. Manajemen Pemasaran Perspektif Asia(terjemahan), Penerbit ANDI, Yogyakarta

15. Lupiyoadi, Rambat. 2001, Manajemen Pemasaran Jasa edisi pertama, Salemba Empat, Jakarta

16. Lee, Jonathan., Lee, Janghyuk., Feick Lawrence. 2001, The impact of Switching Cost on The Customer Satisfaction-Loyalty link: Mobile Phone Service in France. Ournal of Services Marketing. Vol. 15. No. 1 pp. $35-48$

17. Mowen, John C. 1995, Konsumer Behavior, Prentice Hall, Inc, Englewod Cliffs, New Jersey, Internation Edition

18. Musanto Trisno. 2004. Faktor-Faktor Kepuasan Pelanggan dan Loyalitas Pelanggan : Studi Kasus Pada CV. Sarana Media Advertising Surabaya. Jurnal Manajemen dan Kewirausahaan, September Vol 6 no 2, p 123 - 136

19. M. Achsin, 1999. Analisis Dimensi Kualitas Layanan Yang Mempengaruhi Kepuasan Berdasarkan Persepsi Pasien pada Rumah Sakit Muhammadiyah awa Timur, Surabaya

20. Olson, Peter. 1993, Konsumer Behavior and Marketing Strategy, Richard D. Irwan Inc. Boston. Third Edition

21. Paul Peter, J \& Olson, C Jerry, 2000, Konsumer Behavior and Marketing Strategy, edisi 4 (terjemahan), Erlangga Jakarta

22. Payne, Andrian, 2000. Pemasaran Jasa (terjemahan ) edisi 1 cetakan pertama. ANDI, Yogyakarta

23. Rowley \& Dawes. 1999. Customer Loyalty - a elevant Concept For Libraries ?, Library Management, Vol 20 No 6, p $345-351$

24. Singaribuan Masri \& Effendy Sofian. 1995, Metode Peneltian Survai, LP3ES. Jakarta

25. Spreng, Mackinzie \& Olsvskhy, 1996. the American Satisfaction Index : Nature, purpose and Findings, Jurnal of Marketing, october, vol 60, p $7-18$

26. Sugiyono, 2005. Metode Penelitian Administratif, ALFABETA, Bandung

27. Tanjung, JW, 2004. Marketing Strategy In The Indonesia Stting edisi pertama, Spirit, Surabaya

28. Tjiptono, Fandy. 1997, Prinsip-Prinsip Total Quality Service (TQS), ANDI, Yogyakarta

29. Tjiptono, Fandy. 1997, Strategy Pemasaran edisi kedua cetakan pertama, ANDI, Yogyakarta

30. Umar, Husein, 2003. Metode Riset Perilaku Konsumen Jasa, Ghalia Indonesia, Jakarta

31. Wikipedia, 2007. Hasil Riset Sepanjang 2006 Telkomsel Raih Operator Telekomunikasi Terbaik, wikipedia.org/wiki/Telkomsel, 18 April

32. Zaid, Sudirman, 2000. Analisis Pengaruh Kualitas Produk terhadap Kepuasan Konsumen. Studi Kasus Rumah Sederhana dan Rumah Sangat Sederhana, Tesis, Program Studi IImu Manajemen Program Pascasarjana Universitas Airlangga, Surabaya (tidak dipublikasikan)

33. Zaid, Sudirman, 2004, Pengaruh Keahlian Konsumen Dalam Mengolah Informasi Terhadap Loyalitas Nasabah Tabungan, Deposito Dan Giro Pada Bank Rakyat Indonesia Di Sulawesi Tenggara, Disertasi, Program Pascasarjana Universitas Airlangga, Surabaya (tidak dipublikasikan). 